\title{
PARTIAL REPLACEMENT OF CEMENT WITH SUGARCANE BAGASSE ASH IN CONCRETE
}

\author{
Sajan Sharma \\ Department of Civil Engineering \\ Golden Groups of Institutions \\ Gurdaspur, Punjab
}

\begin{abstract}
There are dozen impacts of cement on our environment. More environmental problems are generated by manufacturing of cement in cement industries and they produce $\mathrm{CO}_{2}$ emissions in large amount. Researchers are more focused on the environmental effects. With increases in the demand and consumption of cement, researchers are eagerly in search of inventing secondary materials for binding which can impart the waste management \& ecofriendly. The quantity of waste materials can be reduced by the utilization of industrial and agricultural waste material in construction industries. In this research, sugarcane bagasse ash can be used as a binding material and partial replacement of binding material cement in concrete. The sugarcane bagasse is produced by the sugar mills after the extraction of juice. The sugarcane bagasse ash is obtained when it is burnt in uncontrolled conditions. SCBA is the most part of land fill. Sugarcane bagasse ash is taken from Ludhiana and used as pozzalonic material because it contains pozzalonic properties. In my work, M25 grade of concrete used by replacing of sugarcane bagasse ash $(0 \%, 3 \%, 6 \%, 9 \%$ and $12 \%)$ by weight of cement in concrete. The tests conducted compressive strength at the age of 7 and 28 days. Flexural strength, Split tensile strength, Water absorption, Abrasion resistance and Water permeability test was conducted at the age of 28 days. The tests results of compression, split tensile, flexural strength and permeability increases up to a certain limit, than it start decreasing. The water absorption increases with the increase in the \% of SCBA in concrete.
\end{abstract}

Keywords - SCBA-Sugarcane bagass ash,Sc-Specific gravity of cement, Fck-Characteristic compressive strength,Fc-Target mean strength,Kj-kilo joules, $\mu$-fineness modulus.

\section{INTRODUCTION}

Sugarcane bagasse ash is agro waste material that is replaced in concrete as a cementitious material. Concrete is a homogeneous mixture of cement, fine aggregates, coarse aggregates, water \& admixtures. Sugarcane is the crucial crop in world which is used in sugar mills for more purposes like sugar, juice and jerk. After, the sepration of extract from sugarcane than sugarcane bagasse is obtained. Sugarcane bagasse is used for more purposes in sugar industries. Sugarcane bagasse is an unutilized and waste material which is reused in sugar industries as fuel to generate the heat for boilers and electricity. China is the first country, whose gross production of sugarcane is more than 1510 millions/tons \& India is second another country and its total production of sugarcane is more than 300millions tons/year. Sugarcane bagasse is used to generate the electricity and heat generation for boilers and sugarcane bagasse is burnt for these purposes. After the combustion of sugarcane bagasse ash is formed. This ash is also known as the sugarcane bagasse ash and it is obtained directly from the sugar mills. It is not more reactive because it is scorched under uncontrolled environment and at very high temperatures. After, burning the sugarcane, bagasse ash is produced in large amount of silica, aluminium and calcium oxides. SCBA becomes an industrial waste and its causes more environmental problems developed. In last year's, we studied sugarcane bagasse ash is utilized in the study of pozzalonic action and the quality as binder with partial replacement of cement in concrete $\&$ it also used to analyse the workability, slump, compaction factor, compressive strength etc. in concrete. Most commonly ashes are produced by industrial wastes e.g. fly ash; bagasse ash, blast furnace slag \& silica fume etc. These wastes are used in concrete as additional cementitious material. Presently, there has been used large amount of SCBA in concrete. Consequently, it achievable to use SCBA as partially replaced with cement to modify the quality $\&$ decrease cost of building materials such as soil interlocking blocks, mortar, concrete roof tiles \& concrete pavers etc. SCBA is a waste material \& un-utilized from industries. In first form, we carried out the physical properties, chemical composition of SCBA and characterization of bagasse ash \& this consist of initial setting time, final setting time and water property of blended cement. In second form, we studied on concrete samples. This includes tests split tensile strength, compressive strength, water absorption, permeability and abrasion resistance test etc. SCBA is the one of the main product which is used as a mineral in concrete admixture because it has high silica content. Sugarcane bagasse ash is used in landfills and causes 


\section{International Journal of Engineering Applied Sciences and Technology, 2019 \\ Vol. 4, Issue 4, ISSN No. 2455-2143, Pages 87-93 \\ Published Online August 2019 in IJEAST (http://www.ijeast.com)}

of disposal. Sugarcane bagasse ash consists mostly in large amount of cellulose $(50 \%)$, hemicelluloses of lignin (25\%). Sugarcane bagasse ash is used as fertilizers in farms. OPC (ordinary Portland cement) 53grade is used in concrete mixture and it is replaced with sugarcane bagasse ash in concrete

\section{MATERIAL \& MIX DESIGN}

In order to accomplish the objectives of my study, the experimental programme was planned to check the Split tensile strength, compressive strength, Flexural strength, Abrasion test, Water permeability \& Water Absorption test when SCBA is replaced with different percentages $0 \%, 3 \%, 6 \%, 9 \%, 12 \%$ by the cement in concrete

\section{A. Materials Used}

The specifications of all these materials taken as per IS codes and determined chemical and physical properties experimentally are given below.

a) Cement: In my study, OPC (Ordinary Portland Cement) 53 grades is used in investigation. Mostly, in total production Ordinary Portland Cement is used for $80-90$ percent. It was free from lumps \& fresh. All tests of cement was conducted like consistency tests, Setting tests, fineness test, soundness tests etc. as per procedure arranged as per IS code 12269 1987 and physical properties are given in table:

\section{Physical Properties of Cement}

\begin{tabular}{|c|c|c|}
\hline S No. & Physical Properties & Results Obtained \\
\hline 1 & Normal Consistency & $35 \%$ \\
\hline 2 & Initial setting time & $125 \mathrm{~min}$. \\
\hline 3 & Final setting time & $270 \mathrm{~min}$ \\
\hline 4 & Specific gravity & 2.85 \\
\hline
\end{tabular}

b) Fine Aggregates: Locally available river sand is used as fine aggregates. Sand was tested as per IS code 383-1963. The fine aggregates are free from the impurities like clay, organic and silt. The sand particle also gives to minimum voids ratio, higher voids contents leads to requisite more water for mixing. The various tests are conducted on sand as per the specification of IS code 2386-1963 for determined its physical properties gradation, fineness modulus and specific gravity of sand.

\section{Properties of Fine Aggregates}

\begin{tabular}{|c|c|}
\hline Characteristics & Value \\
\hline Type & Uncrushed (Natural) \\
\hline $\mathrm{Sc}$ & 2.78 \\
\hline Total water absorption & $1.05 \%$ \\
\hline$\mu$ & 2.608 \\
\hline Grading zone & $\mathrm{III}$ \\
\hline
\end{tabular}

c) Coarse Aggregate: The crushed gravel aggregates are used in my study. The largest nominal size is $20 \mathrm{~mm} \& 10 \mathrm{~mm}$ which used in this experimental study. These are tested as per Indian Standard codes in my study. Physical properties of coarse aggregates are specified as per IS codes 383-1963and 2386-1963. These IS codes are preferred for tests of coarse aggregates. The tests conducted fineness modulus, specific gravity, soundness and water absorption on coarse aggregates.

\section{Properties of Coarse Aggregates}

\begin{tabular}{|c|c|}
\hline Characteristics & Value \\
\hline Type & Crushed \\
\hline Max. Size & $20 \mathrm{~mm}$ \\
\hline Sc & 2.825 \\
\hline Total water absorption & $3.645 \%$ \\
\hline$\mu$ & 7.68 \\
\hline
\end{tabular}

d) Water: In my study, potable drinking water is used for mixing and curing of concrete. This is specified as per IS code 456-2000. The water should be potable drinking water \& free from dangerous impurities like alkalis, oil, acids etc. In general, that water is acceptable for drinking is used for concreting.

\section{Chemical Properties of Water}

\begin{tabular}{|c|c|c|}
\hline Sr.No. & Properties & Result Obtained \\
\hline 1 & $\mathrm{pH}$ & 7.12 \\
\hline 2 & $\mathrm{TDS}$ & 0.34 \\
\hline 3 & $\mathrm{TA}$ & 98.83 \\
\hline 4 & $\mathrm{Na}^{+}$ & 9.25 \\
\hline 5 & $\mathrm{~K}^{+}$ & 1.35 \\
\hline 6 & $\mathrm{Ca}^{+2}$ & 38.71 \\
\hline 7 & $\mathrm{Mg}^{+2}$ & 15.34 \\
\hline 8 & $\mathrm{Co}_{3}{ }^{-}$ & 8.59 \\
\hline 9 & $\mathrm{HCO}_{3}^{-}$ & 73.55 \\
\hline 10 & $\mathrm{~F}^{-}$ & 0.61 \\
\hline
\end{tabular}




\begin{tabular}{|l|l|l|}
\hline 11 & $\mathrm{SO}_{4}{ }^{{ }^{-}}$ & 52.22 \\
\hline
\end{tabular}

e) Sugarcane Bagasse Ash: In my study, the SCBA samples are taken from" The Budhewal Co Operative Sugar Mills Limited" in Ludhiana. The sugarcane bagasse ash consist approximately $46-56 \%$ cellulose, $22-26 \%$ hemicelluloses, 1$4 \%$ ash. The sugarcane bagasse contains un-burnt, burnt and half burnt particles when it burnt in mills. Due to presence of these particles SCBA is not used for concreting. After removal of these particles the SCBA is sieved and grinded than it used for concrete. In this present study, the sugarcane bagasse replaced with cement with different percentages $0 \%, 3 \%, 6 \%$, $9 \%, 12 \%$. The chemical properties of SCBA were determined by the company itself.

\section{Physical Properties of SCBA}

\begin{tabular}{|c|c|c|}
\hline Sr.No. & Property & Test Results \\
\hline 1 & Density & $582 \mathrm{~kg} / \mathrm{m}^{3}$ \\
\hline 2 & $\mathrm{Sc}$ & 2.21 \\
\hline 3 & Particle shape & Spherical \\
\hline
\end{tabular}

Chemical Properties of SCBA

\begin{tabular}{|c|c|c|}
\hline Sr.No. & Component & Mass \% \\
\hline 1 & $\mathrm{Si0} 2$ & 78.34 \\
\hline 2 & $\mathrm{Al} 2$ & 8.55 \\
\hline 3 & $\mathrm{Fe} 20$ & 3.61 \\
\hline 4 & $\mathrm{CaO}$ & 2.15 \\
\hline 5 & $\mathrm{Na} 20$ & 0.12 \\
\hline 6 & $\mathrm{~K} 20$ & 3.46 \\
\hline 7 & $\mathrm{MaO}$ & 0.13 \\
\hline 8 & $\mathrm{Tio} 2$ & 0.50 \\
\hline 9 & $\mathrm{BaO}$ & $<0.16$ \\
\hline 10 & $\mathrm{P} 205$ & 1.07 \\
\hline 11 & Loss of ignition & 0.42 \\
\hline
\end{tabular}

\section{B. Mix Design Procedure for Concrete:}

In the research, to calculate the split tensile strength, compressive strength, flexural strength, water absorption, abrasion and permeability parameters by replacement of SCBA with cement are as follows:

- $\quad$ Sugarcane bagasse ash replaced by cement in different percentages $0 \%, 3 \%, 6 \%, 9 \%$ and $12 \%$.

- $\quad$ Mix proportions was obtained and the total number of specimens to be casted for various tests at the ages of 7 and 28 days.
Designation of Concrete Mix

\begin{tabular}{|c|c|c|c|}
\hline S.No & Mix & SCBA (\%) & Cement (\%) \\
\hline 1 & $\mathrm{~A} 0$ & 0 & 100 \\
\hline 2 & $\mathrm{~A} 1$ & 3 & 97 \\
\hline 3 & $\mathrm{~A} 2$ & 6 & 94 \\
\hline 4 & $\mathrm{~A} 3$ & 9 & 91 \\
\hline 5 & $\mathrm{~A} 4$ & 12 & 88 \\
\hline
\end{tabular}

Mix Proportions for Different Concrete Mix $\left(\mathrm{kg} / \mathrm{m}^{3}\right)$

\begin{tabular}{|c|c|c|c|c|c|c|}
\hline & & & & $\mathbf{C}$ & & $\mathbf{A}$ \\
& $\mathbf{C}$ & $\mathbf{S}$ & $\mathbf{F}$ & $\mathbf{0}$ & $\mathbf{W}$ & $\mathbf{d}$ \\
$\mathbf{M}$ & $\mathbf{e}$ & $\mathbf{C}$ & $\mathbf{i}$ & $\mathbf{a}$ & $\mathbf{a}$ & $\mathbf{i}$ \\
$\mathbf{i}$ & $\mathbf{m}$ & $\mathbf{B}$ & $\mathbf{n}$ & $\mathbf{r}$ & $\mathbf{t}$ & $\mathbf{x}$ \\
$\mathbf{x}$ & $\mathbf{e}$ & $\mathbf{A}$ & $\mathbf{e}$ & $\mathbf{~ s}$ & $\mathbf{e}$ & $\mathbf{t}$ \\
& $\mathbf{n}$ & & Agg. & $\mathbf{e}$ & $\mathbf{r}$ & $\mathbf{u}$ \\
& $\mathbf{t}$ & & & Agg. & & $\mathbf{r}$ \\
& & & & & & $\mathbf{e}$ \\
\hline A0 & 340.90 & $\mathrm{~A} 00$ & 886.16 & 1152 & 150 & 3.409 \\
\hline A1 & 306.80 & 34.09 & 886.16 & 1152 & 150 & 3.409 \\
\hline A2 & 272.72 & 68.18 & 886.16 & 1152 & 150 & 3.409 \\
\hline A3 & 238.63 & 102.27 & 886.16 & 1152 & 150 & 3.409 \\
\hline A4 & 204.54 & 136.36 & 886.16 & 1152 & 150 & 3.409 \\
\hline
\end{tabular}

III. TESTING

In the research, specimens are taken from curing water tank after curing of 7 and 28 days. The tests are conducted on these specimens to determine the different parameters and experimental values.

A. Compressive Strength Test: The compressive strength of the casted samples is determine after the curing at ages 7 and 28 days and tested instantly after the removal from water. Surface water allowed to flow downward. The position of cubes while testing was at right angles to that of casting position. The load was gradually applied without any shock and increased at constant rate of $14 \mathrm{~N} / \mathrm{mm}^{2}$ until failure of specimens take place. The test was conducted according to as per IS code 516-1979. The test was conducted on compression testing machine and the compressive values can be calculated by given formula:

Compressive Strength, $\mathrm{Fc}=\frac{P}{A}$ 


\section{International Journal of Engineering Applied Sciences and Technology, 2019 \\ Vol. 4, Issue 4, ISSN No. 2455-2143, Pages 87-93 \\ Published Online August 2019 in IJEAST (http://www.ijeast.com)}

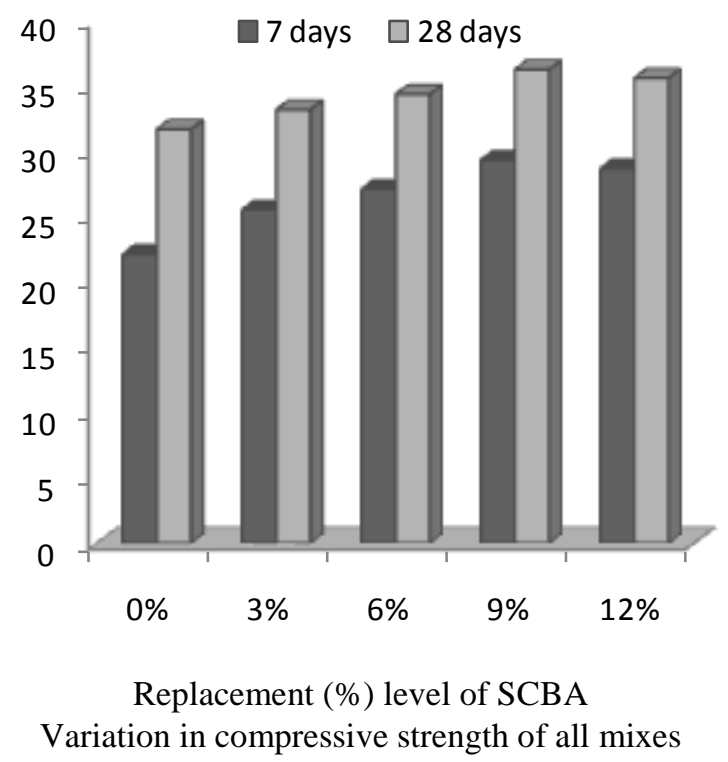

B. Split Tensile Strength Test: The split tensile strength of casted specimens is determined at the ages of 28 days during curing period. The load is applied gradually on the cylinders without shock and increased the constant rate of load in $\mathrm{N} / \mathrm{mm}^{2}$ until failure takes place on specimens. The tensile strength of concrete is calculated by splitting the specimen across vertical dia. This test is an indirect method of calculating the tensile strength of concrete sample. As per IS 58161999 the test are performed by placing the cylindrical sample horizontally between the compressing surfaces of a compression testing machine. The compression was applied until the sample cracks or fails. The split tensile strength is calculated using the formula, $\mathrm{F}=\frac{2 P}{\pi d L}$

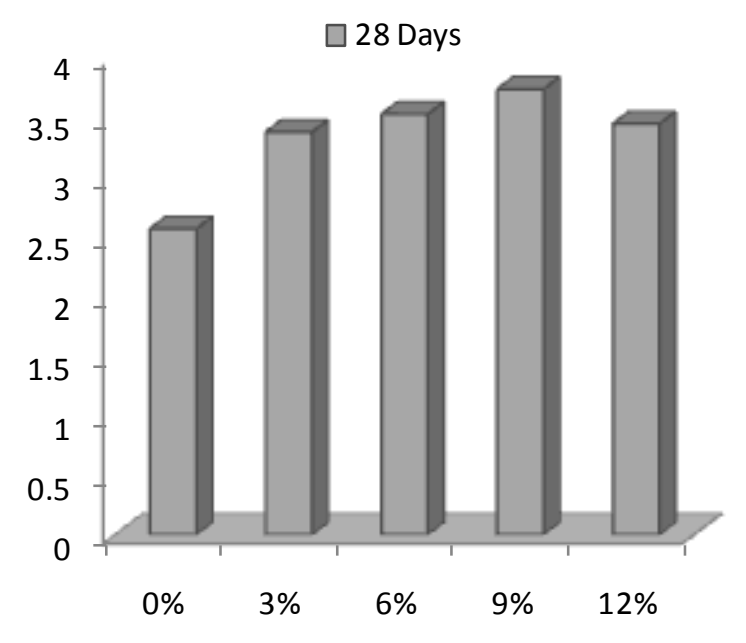

Replacement (\%) Level of SCBA

Variation in Split Tensile Strength of all mixes
C. Flexural Strength Test: For flexural strength the casted beams was taken from the curing tank at age of 28 days after curing and tested after the surface water flow downward from the surface of specimens. The tests conducted on universal testing machine (UTM). The standard size of the sample $100 \mathrm{x}$ $100 \times 500 \mathrm{~mm}$ is used. The mould used is made of metal or cast iron, with enough plate thickness to prevent warping or spreading. The load is applied through the roller placed at middle (central point load). The flexural strength of specimen is represented \& calculated as modulus of rupture by below formula.

$\mathrm{Fb}=7.5 \sqrt{f c^{4}}$

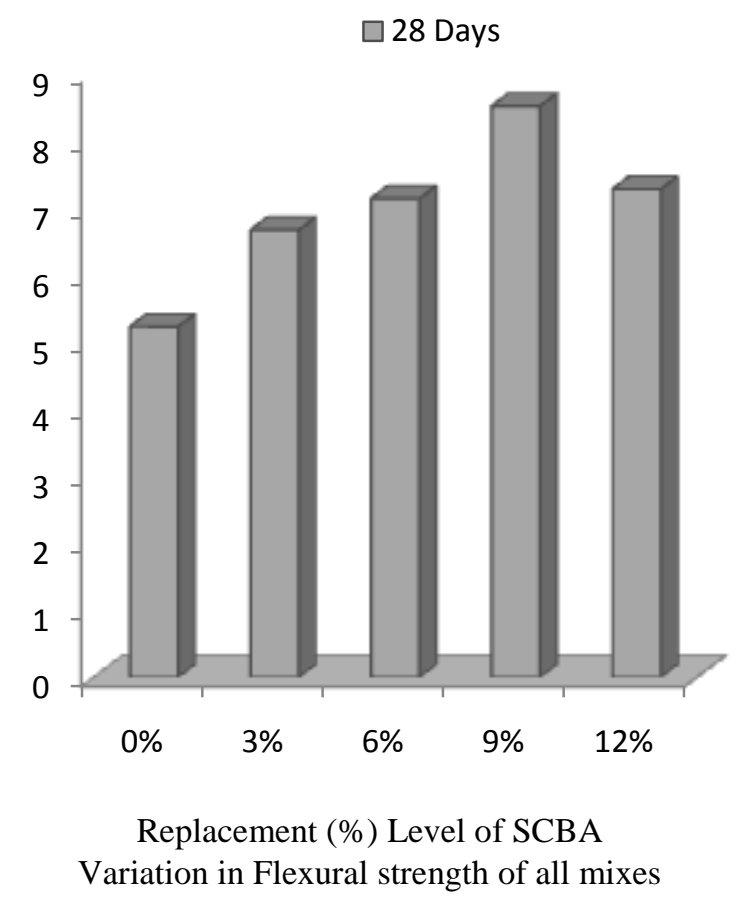

D. Water Absorption Test: In this test, the casted specimens 150x 150x $150 \mathrm{~mm}$ cubes are curing at the age of 28 days of curing period. After moist curing the samples take place in oven for 24 hours than the dry weight of the specimens determined. The specimens immersed in curing tank for 24 hours after the removal from curing tank. The percentage of water absorption is measured of the porosity and volume of voids in hardened concrete. The test applied on hardened concrete. The test conducted as per ASTM C642. The water absorption expressed as in percent.

$\%$ of water absorption $=\left[\frac{\text { Wet Wt. }- \text { Dry Wt. }}{\text { Dry Wt. }}\right]$ X100 


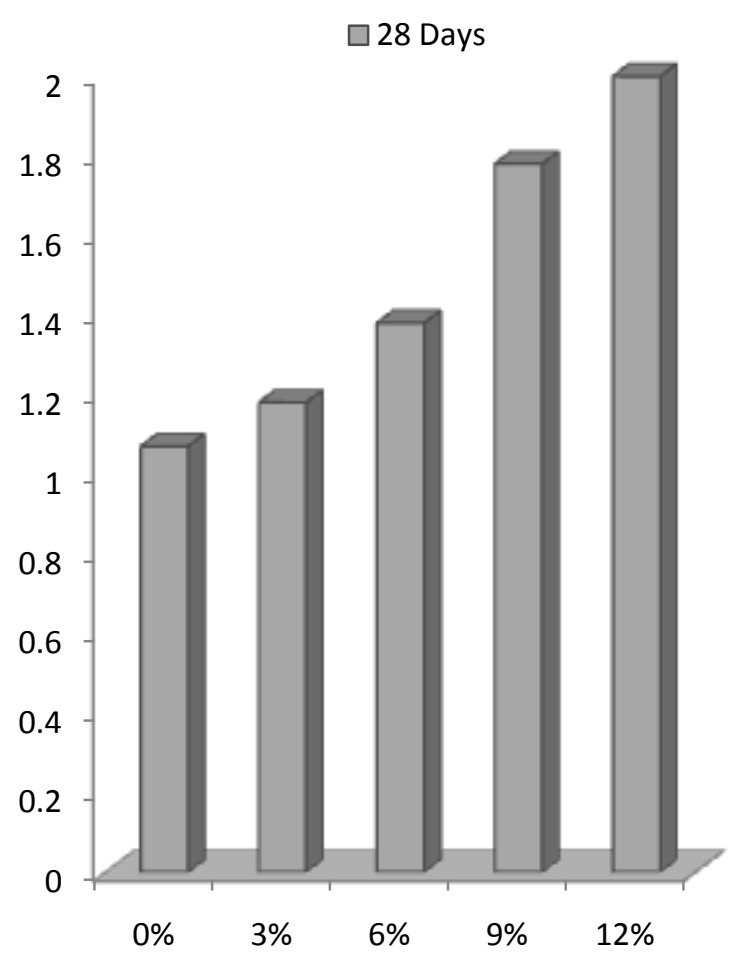

Replacement (\%) Level of SCBA
Variation in Water Absorption

E. Abrasion Resistance Test: The abrasion test conducted on hardened concrete as per IS code 9284-1979. The $70 \times 70 \times 70 \mathrm{~mm}$ size of cubes was casted for abrasion test. Test was conducted at the 28 days after the curing. The cubes placed in oven at $50^{\circ} \mathrm{C}$ and removed for test. The surface of the specimens should be rubbed with mineral paper to remove cement laitance and expose aggregates particle from the surface of cubes, before conducting the test. Abrasion loss of specimen shall be taken as the loss of mass in grams for two separation impressions on the similar face of the concrete sample under test. The procedure should be repeated on the other three vertical faces of the same sample. The test shall be repeated on the same surface after rotating the sample at $180^{\circ} \mathrm{C}$. The abrasion loss of concrete as the average of the results obtained for the 12 surfaces (that is 4 surfaces for each 3 cubes) and expressed in percent loss. Can be Calculated by using: $m=m 1-m 2, m=$ loss of mass in $g, m 1=$ mass of the specimen before each test in $\mathrm{g}, \mathrm{m} 2=$ mass of the specimen after each test in $\mathrm{g}$.

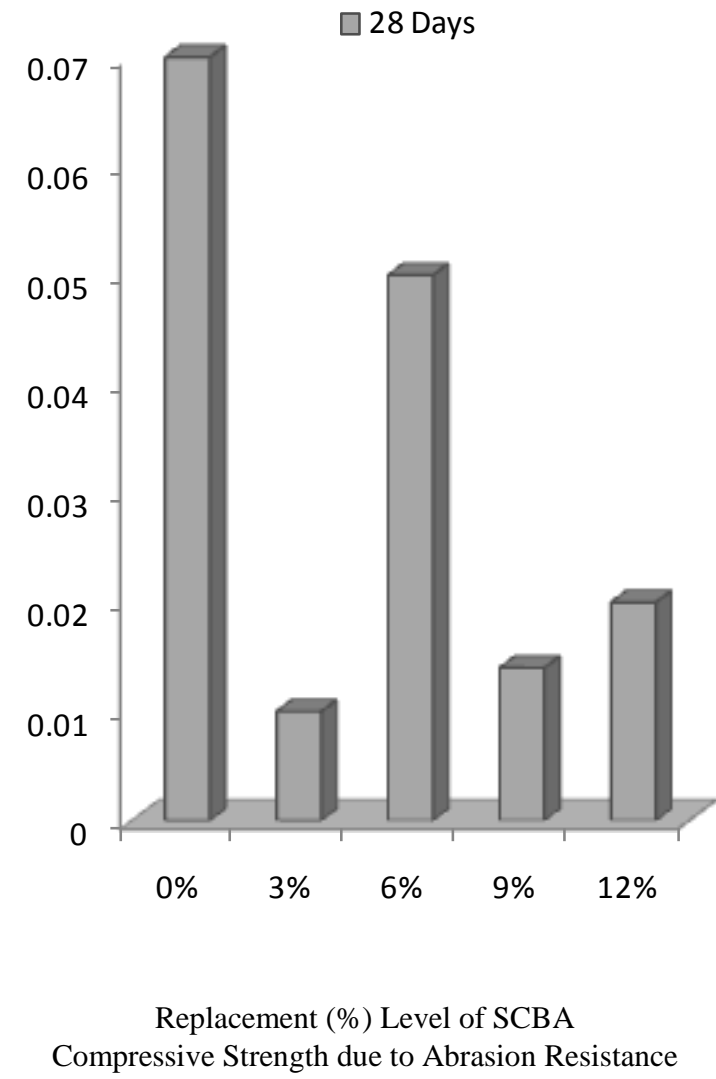

F. Water Permeability Test: The permeability test was conducted as per code 3085-1965. The specimens shall be cube in shape with height of equal width. The size of the cube sample taken is $150 \times 150 \times 150 \mathrm{~mm}$. The specimens shall be cured at the age 28 days. The specimens shall be cleaned with stiff wire brush to remove all laitance. The cube specimens shall be placed in the permeability cell. The space between the specimen and cell shall be tighten with a cotton and other melting compounds. The wax and lac used for sealing the compounds. After this Sikkadur 31 (Epoxy Grout) applied equally at the top surface of specimen with wax and lac layers when lac and wax freezes, than the cell connected to the water reservoir. The pressure head to be applied to the water in the reservoir should be $10 \mathrm{~kg} / \mathrm{cm}^{2}$ and it reduced up to $5 \mathrm{~kg} / \mathrm{cm}^{2}$. Calculation:The coefficient of permeability shall be calculated as follows: $\mathrm{K}=\frac{\mathrm{QL}}{\mathrm{ATH}}$ 


\section{International Journal of Engineering Applied Sciences and Technology, 2019 \\ Vol. 4, Issue 4, ISSN No. 2455-2143, Pages 87-93 \\ Published Online August 2019 in IJEAST (http://www.ijeast.com)}

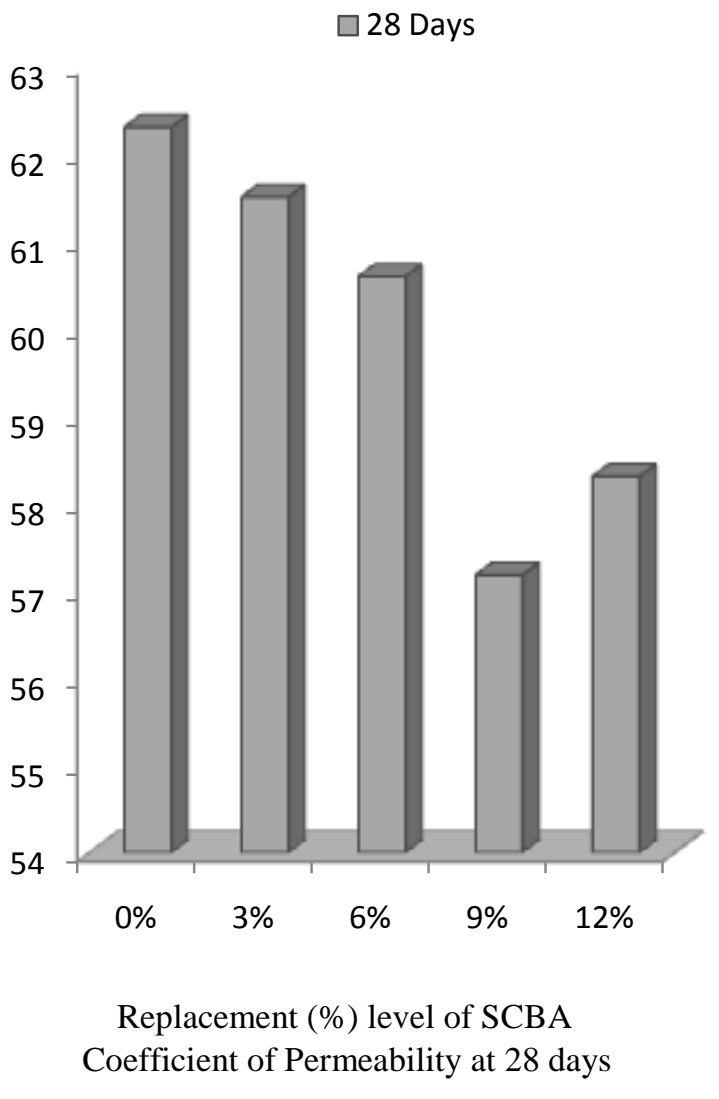

\section{CONCLUSION}

The present work was understood to study of Split Tensile Strength, Compressive Strength, Flexural Strength, Abrasion Resistance, Water Absorption \& Permeability. Cubes $(150 \mathrm{~mm} * 150 \mathrm{~mm} * 150 \mathrm{~mm})$ and cubes $(70 \mathrm{~mm} * 70 \mathrm{~mm} * 70 \mathrm{~mm})$, Cylinders $(300 \mathrm{~mm} * 150 \mathrm{~mm})$ and beams $(100 \mathrm{~mm} * 500 \mathrm{~mm} *$ $100 \mathrm{~mm}$ ) were casted and tested for these parameters to take the strength. The tests are performed on fresh \& hardened concrete. The major conclusion drawn from the present study:

- The compressive strength of the concrete increases with up to $9 \%$ of sugarcane bagasse ash replaced with cement at 7 days $29.37 \mathrm{~N} / \mathrm{mm}^{2}$ and at 28 days $36.33 \mathrm{~N} / \mathrm{mm}^{2}$.

- The split tensile strength increases upto $9 \%$ of SCBA replaced with cement in concrete at 28 days $3.73 \mathrm{~N} / \mathrm{mm}^{2}$.

- The flexural strength increases maximum up to $9 \%$ of SCBA replaced in concrete with cement at 28 days 8.52 $\mathrm{N} / \mathrm{mm}^{2}$.

- The split tensile strength, compressive strength \& flexural strength increases with increases the percentages of sugarcane bagasse ash upto a certain limit.

- The percentages of water absorption increases with increases the \%age of sugarcane bagasse ash in concrete because they have un-burnt, burnt and half burnt particles. These particles also absorbed more water.

- The total weight loss of cubes has minor difference with increases the percentages of sugarcane bagasse ash due to abrasion resistance test. After abrasion test the compressive strength of cubes $(70 * 70 \mathrm{~mm})$ increases upto a certain limit than strength decreases.

- The permeability of Ordinary Portland Cement \& SCBA decreases with increase in curing period of samples.

The results obtained from my study shows that up to $9 \%$ of SCBA could be advantageously mixed with cement without oppositely affecting the strength \& permeability of concrete.

\section{REFERENCE}

[1] Abdulkadir T.S et.al (2014) "Evaluation of sugar cane bagasse ash as a partial replacement for cement in concrete works" ACTA Tecnica Corviniensis, Vo1.7.

[2] Anand Ankur "Comparative study of concrete strength by partially replacement cement with sugarcane bagasse ash and fly ash" International Journal of Science, Engineering and Technology, Vo1.5.

[3] ASTM 642-97 "Test methods for specific gravity, water absorption and voids on hardened concrete".

[4] Bangar S. et.al (2017) "An experimental study on replacement of cement with sugarcane

[5] bagasse ash" International Journal of Engineering and Science Management, Vol.1.

[6] BIS- IS 10262 : 2009 "Indian Standard recommended guidelines for concrete mix design"- Bureau of Indian Standards, New Delhi, India.

[7] BIS- IS $12269: 1999$ "Specification for 53 grade ordinary Portland cement" Bureau of

[8] Indian Standards, New Delhi, India.

[9] BIS- IS 387 : 1970 "Specification for coarse and fine aggregates for natural sources for concrete".

[10] BIS- IS 456: 2000 "Code of practice for plain and reinforced concrete".

[11] BIS- IS 3085 : 1965 "Method of test for permeability of cement mortar and concrete".

[12] BIS- IS $9284: 1979$ "Methods of test for abrasion resistance of concrete".

[13] Dharanidheran S. et.al (2015) "Rajkumar Experimental study on mechanical properties of concrete by using sugarcane bagasse ash International Journal of Engineering Science and Research Technology, Vol. 4.

[14] Ganesan K. , Rajagopal et.al (2007) "Evaluation of bagasse ash as supplementary cementitious material" ELSEVIER.

[15] Kotresh K. M. et.al (2014) "Study on performance of sugar cane bagasse ash waste as a concrete cement" 
International Journal of Research in Engineering and Technology, Vol. 2.

[16] Lakshmi Priya, Ragupathy et.al (2016) "Effect of sugarcane bagasse ash on strength properties of concrete" International Journal of Engineering, Research and Technology, Vol.5.

[17] Nidhi Relan et.al (2015) "Experimental study of replacement of cement by sugarcane bagasse ash in concrete" International Journal of Science and Research" Vol. 4.

[18] Modani Parshant et.al (2013) "Utilization of bagasse ash as a partial replacement of fine aggregates in concrete" ELSEVIER.

[19] Prasanna Maneeth, Bhushan et.al (2016) "Experimental investigation partial replacement of cement by sugarcane bagasse ash in concrete" International Journal of Scientific Research and development, Vol. 3.

[20] Sachin M. , Raj et.al (2017) "Study on replacement of cement in concrete with sugarcane bagasse ash and coir fibre" Imperial Journal of Interdisciplinary Research, Vol. 3.

[21] Srinivasan R. et.al (2010) "Experimental study on bagasse ash in concrete" International Journal for Service Learning in Engineering, Vol. 5.

[22] T.Malyadari et.al (2015) "Experimental study on sugarcane bagasse ash in concrete by partially replacement with cement" International Journal of Computer Engineering in Research Trends, Vol. 2.

[23] U.R. Kawade. Rathi et.al (2013) "Effect of use of sugarcane bagasse ash on strength of concrete" International Journal of Innovative Research in Science, Engineering and Technology, Vol. 2.

[24] Y. R. Loh et.al (2013) "Sugarcane bagasse ash - The future composite material ELSEVIER. 